\title{
Planning Landscape Connectivity in Mexico under Global Change
}

Oscar Godínez-Gómez ${ }^{\ddagger}$, Angela Patricia Cuervo-Robayo ${ }^{\ddagger}$, Diana Ramírez-Mejía ${ }^{\ddagger}$, Wolke Tobón , Jesús Alarcón $n^{\ddagger}$, Patricia Koleff ${ }^{\ddagger}$, Tania Urquiza-Haas ${ }^{\ddagger}$

‡ National Commission for the Knowledge and Use of Biodiversity, Mexico city, Mexico

Corresponding author: Tania Urquiza-Haas (turquiza@conabio.gob.mx)

Received: 11 Jul 2019 | Published: 17 Jul 2019

Citation: Godínez-Gómez O, Cuervo-Robayo AP, Ramírez-Mejía D, Tobón W, Alarcón J, Koleff P, Urquiza-Haas T

(2019) Planning Landscape Connectivity in Mexico under Global Change. Biodiversity Information Science and Standards 3: e38199. https://doi.org/10.3897/biss.3.38199

\begin{abstract}
Climate change, habitat loss and fragmentation, invasive species, and resource overexploitation are among the major factors driving biodiversity loss and the current global change crisis. Maintaining and restoring connectivity throughout fragmented landscapes is key to reduce habitat isolation and mitigate anthropogenic impacts. To date, few connectivity approaches seek to identify corridors along climate gradients and least transformed natural habitats despite its importance to facilitate dispersal of organisms, as species' ranges shift over time to track suitable climates. In this study, we identified leastcost climatic corridors in Mexico between 2027 old-growth vegetation patches incorporating evapotranspiration as climatic variable, Euclidean distances, and human impact. We identified old-growth vegetation patches using the land use and vegetation map of 2011 (scale 1:250 000) by the National Institute of Statistics and Geography (INEGI). Moreover, we calculated a human impact index based on the theoretical framework of the Global Biodiversity Model (Alkemade et al. 2009) but adapted for Mexico (Mexbio, Kolb 2016), and includes the impact of land use, road infrastructure and fragmentation based on the land use and vegetation map of 2011 and a road map by the Mexican Institute of Transportation. We modeled corridors for a baseline period (1980-2009) and under three future time periods (2015-2039, 2045-2069 and 2075-2099), corresponding to four Global Circulation Models (MPI-ESM-LR, GFDL-CM3, HADGEM2ES and CNRMCM5) each under two emission scenarios (RCP 4.5 and 8.5) The historical
\end{abstract}


and future evapotranspiration values were calculated using the climate surfaces from Cuervo-Robayo et al. 2019 and from the Center of Atmospheric Sciences of the National Autonomous University of Mexico*1, respectively. The historical and future evapotranspiration values were calculated using the climate surfaces from Cuervo-Robayo et al. 2019 and from the Center of Atmospheric Sciences of the National Autonomous University of Mexico, respectively. We used the Turc evapotranspiration equation (Turc 1954) to estimate actual evapotranspiration. Least cost climatic corridors using future climate projections were used to test the assumption that climatic gradients are maintained in the future. We then prioritized climatic corridors using a multicriteria analysis guided by expert knowledge, incorporating factors such as indicators of human impact, vulnerability and exposure to climate change, and priority sites for biodiversity conservation and restoration. On average, more than 4,500 least cost climatic corridors were identified for each scenario. There is a high spatial coincidence in the geographical location of current and future climatic corridors (overlap > 90\%). Fewer corridors were identified in the northern part of the country where natural vegetation is less fragmented, whereas in central and southern Mexico landscape fragmentation is greater, resulting in an increased number of corridors (Fig. 1). The use of open spatial data was key in identifying climatic corridors in order to support decision-making. The results provide a spatial guide to implement conservation and restoration actions to promote connectivity, in particular among climatic stable areas, thus supporting the achievement of Aichi Targets and Sustainable Development Goals. Also, it informs multiple stakeholders and sectors in landuse planning decisions and to promote the alignment of existing incentives to reduce habitat loss, degradation and fragmentation in key areas needed to maintain and recover landscape connectivity in the face of global change.

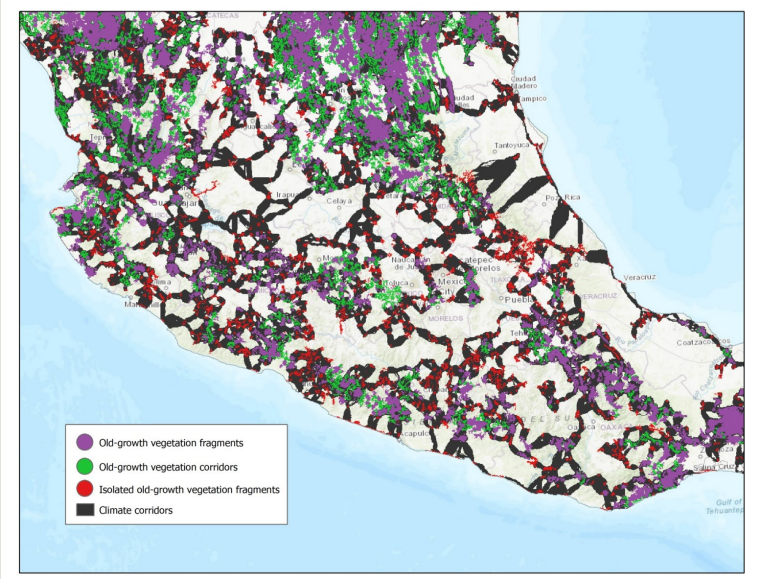

Figure 1.

Proposed corridors to achieve climate connectivity in central Mexico (modeled for the baseline period 1980-2009). 


\section{Keywords}

climate change, landscape connectivity, guide spatial allocation of conservation resources

\section{Presenting author}

Patricia Koleff

\section{Presented at}

Biodiversity_Next 2019

\section{References}

- $\quad$ Alkemade R, van Oorschot M, Miles L, Nellemann C, Bakkenes M, ten Brink B (2009) GLOBIO3: A framework to investigate options for reducing global terrestrial biodiversity loss. Ecosystems 12 (3): 374-390. https://doi.org/10.1007/s10021-009-9229-5

- $\quad$ Cuervo-Robayo AP, Ureta C, Gómez-Albores MA, Meneses-Mosquera AK, Téllez-Valdés O, Martínez-Meyer E (2019) One hundred years of climate change in Mexico. PLOS One.

- Kolb M (2016) Indicadores de impacto humano, herramienta para evaluar el estado de conservación de la biodiversidad. In: CONABIO Capital natural de México, Vol. IV. Capacidades humanas e institucionales. CONABIO, Mexico, 337-340 pp.

- Turc $L$ (1954) The water balance of soils:Relation between precipitation, evaporation and flow. Annales Agronomiques 5: 491-569.

\section{Endnotes}

*1 Downloaded from http://atlasclimatico.unam.mx:8550/geonetwork/srv/spa/main.home at a spatial resolution of $30 " \times 30 "$ 